\title{
PELATIHAN ENTREPRENEURSHIP MELALUI PEMBUATAN SELAI KOLAVSA (KOLANG-KALING VARIAN RASA) DI DESA SAGARA KECAMATAN ARGAPURA
}

\author{
Muhamad Kurnia Sugandi, Ipin Aripin, Iim Halimatul Mu'minah \\ Universitas Majalengka, Indonesia \\ kurniasugandi@unma.ac.id
}

\begin{abstract}
The problem experienced by the entrepreneurs of the fusion is the low innovation of processed products to be ready-to-serve products, sales of the fro will be high during the month of Syaban and Ramadan. The purpose of this training activity is to increase the knowledge of the entrepreneurs in processing the products of the fro into a more varied food processing material, and to increase the innovation and creative of the entrepreneurs of the fro through processed Kolavsa jam (flavors of variant flavors) with a combination of dragon fruit, pineapple, chocolate, which are in great demand by all walks of life. The method used in this training is lecture and practice. As a result of this training the participants will be motivated to do creative and innovative entrepreneurship. The response of participants to the training activities was very positive as seen from the enthusiasm of the participants during the activity.
\end{abstract}

Keywords: Entrepreneurship training, jam variant flavors

\begin{abstract}
Abstrak
Permasalahan yang dialami oleh pengusaha kolang-kaling yaitu rendahnya inovasi olahan kolangkaling menjadi produk yang siap saji, penjualan kolang-kaling akan tinggi pada saat bulan Syaban dan Ramadhan. Tujuan dari kegiatan pelatihan ini adalah menambah pengetahuan pengusaha kolang-kaling dalam mengolah produk kolang-kaling menjadi bahan olahan pangan yang lebih bervariasi, dan meningkatkan inovasi dan kreatif pengusaha kolang-kaling melalui olahan selai kolavsa (kolang-kaling varian rasa) dengan kombinasi buah naga, nanas, cokelat, yang banyak diminati oleh semua kalangan. Metode yang digunakan pada pelatihan ini adalah ceramah dan praktik. Hasil dari pelatihan ini peserta menjadi termotivasi untuk melakukan wirausaha yang kreatif dan inovatif. Respon peserta terhadap kegiatan pelatihan ini sangat positif terlihat dari antusias peserta pada saat kegiatan.
\end{abstract}

Kata Kunci: Pelatihan entrepreneurship, selai kolang-kaling varian rasa

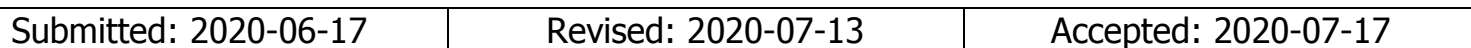

\section{Pendahuluan}

Pelatihan entrepreneurship adalah suatu kegiatan untuk mempersiapkan calon wirausaha yang kreatif dan inovatif agar bisa bersaing dengan situasi keadaan pasar. Lumpkin and Dess (1996) menyatakan bahwa wirausaha harus memiliki tiga dimensi orientasi entrepreneurship yaitu : inovasi (innovativeness), proaktif (proactiveness), dan pengambilan risiko (risk taking). Apabila suatu perusahaan sudah berorientasi entrepreneurship maka akan melakukan inovasi produk baru, memiliki keberanian mengambil risiko dalam setiap keputusan strategis dan selalu proaktif terhadap perubahan tuntutan lingkungan atau konsumen akan produk baru. Adanya sebuah orientasi tersebut akan membentuk usaha mikro, kecil, menengah (UMKM) akan semakin kokoh dan berkembang walaupun persaingan berwirausaha yang semakin ketat. 
Kriteria UMKM berdasarkan UU nomor 20 tahun 2008 menyatkan bahwa, ada pengelompokan UMKM ditinjau dari jumlah omset dan aset yang dimiliki oleh suatu perusahaan. Usaha mikro adalah suatu usaha yang memiliki kekayaan bersih maksimal Rp. 50.000.000 tidak termasuk bangunan/tanah tempat usahanya. Omset penjualan usaha mikro per tahun paling banyak Rp. 300.000.000. Usaha kecil adalah suatu usaha yang memiliki kekayaan bersih maksimal mencapai Rp. 50.000.000, dan omset penjualan per tahun Rp. 500.000.000 sampai 2.500.000.000. Sedangkan usaha menengah sudah masuk kategori usaha yang besar dengan kekayaan bersih maksimal mencapai Rp. 500.000 .000 sampai Rp. 10.000.000.000, dengan omset penjualan pertahun Rp. 2.500.000.000 sampai Rp. 50.000.000.000.

Pohon aren (Arenga pinnata Merr.) termasuk kedalam famili Aracaceae adalah pohon yang banyak menghasilkan bahan-bahan industri, hampir semua bagaian fisik dari pohon ini dapat dimanfaatkan serta memiliki nilai ekonomis (Lempang, 2012). Penyebaran pohon aren tersebar secara alami di wilayah Asia pada daerah tropis di ketinggian $500-$ $1000 \mathrm{mdpl}$ yang memiliki curah hujan tinggi dan memiliki suhu optimal rata-rata $25^{\circ} \mathrm{C}$ (Nidya, 2012). Indonesia sebagai salah satu penyebaran pohon aren tersebar di daerah Sumatera, Jawa, Kalimantan, Sulawesi, dan Maluku. Pohon ini tumbuh dengan subur dan bukan termasuk tumbuhan yang dibudidayakan. Salah satu bahan industri pangan yang dihasilkan dari pohon ini yaitu buahnya yang dikenal dengan buah kolang-kaling. Merurut Berta, Koapaha, Mendey (2018) Kandungan gizi kolang-kaling per 100 gram mengandung kalori 27 kkal, protein 0,4 gram, lemak 0,2 gram, karbohidrat 6 gram, kalsium $91 \mathrm{mg}$, posfor $234 \mathrm{mg}$, serat $1,6 \mathrm{~g}$, dan zat besi $0,5 \mathrm{mg}$. Kolang-kaling sangat bermanfaat bagi kesehatan salah satunya dapat memulihkan stamina tubuh, menyegarkan tubuh, dan memperlancar metabolisme tubuh (Novayanti, S.R., 2016). Manfaat lain dari kolang-kaling menurut Riza, E. (2016) meyebutkan bahwa kolang-kaling dapat mengatasi radang sendi, melancarkan pencernaan, memperkuat tulang dan sebagai makanan diet. Berdasarkan kandungan gizi dan manfaatnya banyak orang yang mencari dan mengkonsumsi kolangkaling bahkan dikalangan wirausaha dijadikan sebuah peluang usaha yang dapat meraih keuntungan cukup besar. Pengusaha kolang-kaling ini bisa dijumpai di beberapa daerah yang menjadi tempat penyebaran pohon aren. Salah satu sentral kolang-kaling di Jawa Barat adalah di Kabupaten Majalengka.

Blok Galasri yang masuk ke wilayah pemerintahan desa Sagara Kecamatan Argapura Kabupaten Majalengka terdapat pasangan suami istri yang menjadi pengusaha kolang-kaling yaitu bapak Nanang Mustopa dan ibu Sri Mulyati. Mereka mulai merintis usahanya pada tahun 2015, dengan 12 orang karyawan sampai dengan sekarang sebagai usaha turun temurun dari orang tuanya. Produksi kolang-kaling di sini dalam sehari mencapai $10 \mathrm{~kg}$, dengan bahan baku 1 cold bak dari petani kolang-kaling. Proses produksi bisa memerlukan waktu 3 hari, dimulai dari proses perebusan selama 3 jam, pengupasan, dan penggeprekkan. Proses pemasaran maksimal lebih dari 10 hari kolangkaling terjual, hal ini dilakukan agar tetap menjaga kualitas kolang-kaling. Blok Galasri yang berbatasan dengan wilayah Kecamatan Banjaran Kabupaten Majalengka, merupakan salah satu daerah yang banyak ditumbuhi oleh pohon aren. Salah satu Desa di wilayah Kecamatan Banjaran yang dikenal sebagai sentral penghasil kolang-kaling adalah Desa Cimeong, dan Desa Girimulya. Berbeda dengan dulu saat ini pohon aren di daerah tersebut sudah banyak yang ditebang sehingga tidak sebanyak dulu. Para pengusaha 
kolang-kaling mendapatkan bahan bakunya dari daerah kebun perhutani Cipasung Kuningan.

Hasil observasi pendahuluan dengan melakukan wawancara langsung terhadap pengusaha kolang-kaling yang berada di daerah tersebut bahwa kolang-kaling dijual dalam bentuk bahan mentah yang belum diolah menjadi olahan pangan. Karakteristik buah kolang-kaling tidak berasa, tidak berwarna, dan bertekstur kenyal kayak jelly. Dilihat dari karakteristiknya sangat memungkinkan produk kolang-kaling dikombinasikan dengan buah-buahan yang memiliki rasa, aroma dan warna yang khas. Pengusaha kolang-kaling belum bisa mengolah kolang-kaling menjadi produk pangan, sehingga diperlukan adanya sebuah inovasi produk pangan dari kolang-kaling yang menarik dan disukai banyak orang. Penjualan kolang-kaling mengalami peningkatan omzet yang maksimal pada bulan Syaban - Ramadhan. Produksi kolang-kaling saat bulan Syaban - Ramadhan mencapai 10 ton/bulan, sedangkan pada hari-hari biasa hanya mencapai $30-35 \mathrm{~kg} /$ bulannya. Hal ini dapat disimpulkan bahwa konsumen kolang-kaling tidak setiap hari mengkonsumsi kolang-kaling, karena rendahnya inovasi pangan dari produk kolang-kaling siap saji yang dapat dijadikan bahan makanan setiap hari.

Penelitian yang telah dilakukan oleh Hadiyanti (2012) tentang Kreativitas dan Inovasi Pengaruhnya terhadap Pemasaran Entrepreneurship pada Usaha Kecil, menunjukkan bahwa hasilnya kreativitas dan inovasi berpengaruh secara signifikan terhadap pemasaran entrereneurship pada usaha kecil. Kegiatan pelatihan entrepreneurship melalui pembuatan selai kolavsa (kolang-kaling varian rasa), diharapkan bisa menjadi sumber informasi dan memotivasi bagi para pengusaha kolang-kaling khususnya yang berada di blok Galasri Desa Sagara Kecamatan Argapura untuk bisa kreatif dan berinovasi dalam mengolah produk kolang-kaling yang lebih menarik dan menjadi produk pangan yang bisa dijadikan makanan sehari-hari. Selai kolang-kaling pada pelatihan ini akan dikombinasikan dengan buah-buahan yang memiliki cita rasa yang khas yaitu, buah naga, nanas, dan cokelat. Sehingga dengan kombinasi buah-buahan tersebut dapat menarik minat konsumen yang dapat dijadikan bahan makanan sehari-hari. Selai merupakan produk olahan pangan, berupa bubur dari buah-buahan dengan cara dimasak menggunakan gula sampai mengental, yang biasa dikonsumsi dipadukan dengan roti, kue, dan lain-lain. Melalui selai kolavsa ini diharapkan akan menjadi inovasi olahan kolang-kaling yang akan meningkatkan omzet penjualan kolang-kaling pada hari-hari biasa diluar bualan Syaban dan Ramadhan. Selai kolavsa ini dibuat tidak menggunakan bahan pengawet yang bisa bertahan sampai dengan 5 hari di dalam lemari es.

\section{Metode}

Kegiatan pelatihan entrepreneurship melalui pembuatan selai kolavsa (kolangkaling varian rasa) ini mempunyai sasaran terhadap pengusaha kolang-kaling beserta karyawannya, yang berada di Blok Galasri Desa Sagara Kecamatan Argapura Kabupaten Majalengka. Adapun pemilihan tempat ini berdasarkan hasil observasi awal bahwa terdapat permasalahan mitra, yaitu belum ada inovasi dan kreativitas dalam mengolah kolang-kaling menjadi olahan pangan yang menarik dan siap saji. Melalui kegiatan ini diharapkan akan meningkatkan kreativitas pengusah kolang-kaling dan karyawannya agar 
bisa mendapatkan penghasilan tambahan dari hasil penjualan selai kolavsa ini. Kegiatan pelatihan ini terdiri dari langkah-langkah berikut :

1. Tahap Persiapan

Tahap ini terdiri dari :

a. Survey

Survey merupakan tahap awal, dilakukan dengan cara wawancara langsung terhadap pengusaha kolang-kaling dan karyawannya di Blok Galasri Desa Sagara, tujuan survey yaitu untuk mencari tahu apa yang menjadi permasalahan dan kendala dalam usaha yang dilakukannya.
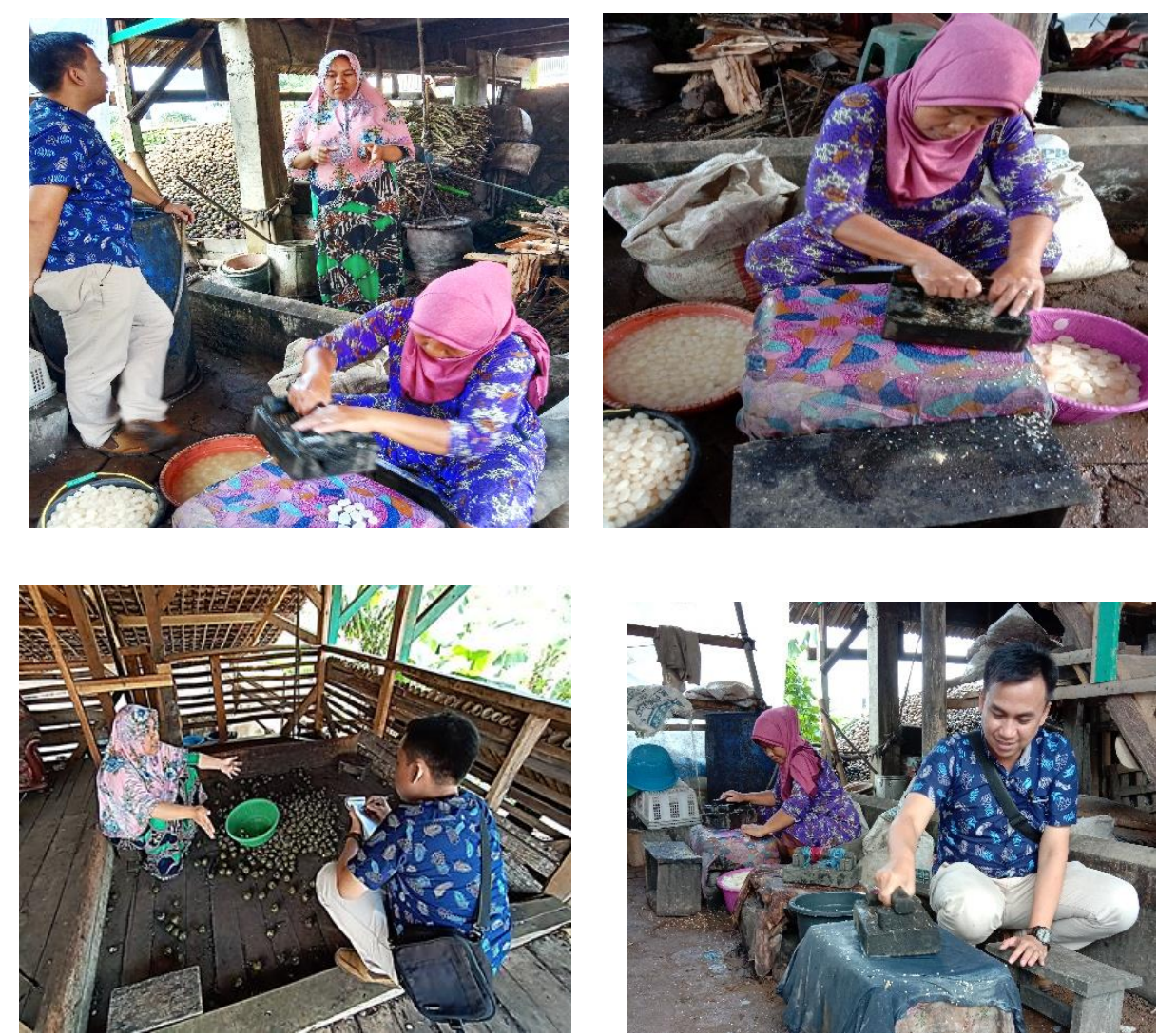

Gambar 1. Survey ke Lokasi Pelatihan

b. Koordinasi ke Pusat Penelitian dan Pengabdian Masyarakat (P3M) Universitas Majalengka.

P3M sebagai lembaga yang memfasilitasi kegiatan ini, sudah seharusnya tim pengabdian kepada masyarakat melakukan koordinasi dengan P3M bertujuan untuk membuat surat tugas untuk melaksanakan kegiatan pelatihan yang ditujukan pada kepala desa Sagara.

c. Pemantapan Terhadap Lokasi Kegiatan

Tahap ini tim dengan membawa surat tugas melakukan kunjungan kembali ke lokasi yang akan dijadikan sebagai sasaran kegiatan pelatihan, hal ini bertujuan untuk mensosialisasikan dan pendataan calon peserta pelatihan yang akan dilaksanakan. 

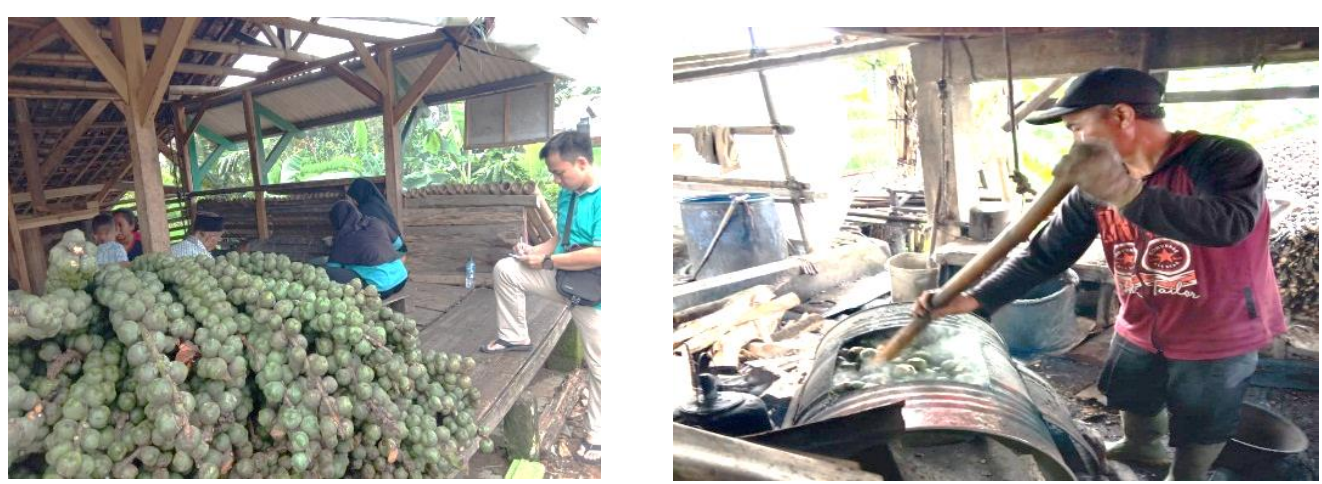

Gambar 2. Pemantapan Terhadap Lokasi Kegiatan

d. Penyusunan Materi Pelatihan

Materi pelatihan disusun dalam bentuk power point berisi tentang permasalahan mitra, pengolahan kolang-kaling secara umum, solusi yang ditawarkan, kandungan dan manfaat kolang-kaling, dan resep pembuatan selai kolavsa dengan varian rasa buah naga, nanas, dan cokelat. Print out materi pelatihan yang dibagikan kepada peserta untuk melakukan praktik pembuatan selai kolavsa di rumah masingmasing.

e. Persiapan Alat dan bahan Praktik Pembuatan Selai Kolavsa

Alat-alat untuk praktik pembuatan selai kolavsa terdiri dari blender, panci, timbangan digital, dan wadah kemasan. Bahan-bahan yang dipergunakan terdiri dari kolang-kaling 100 gram, buah perasa (buah naga, nanas, cokelat) masingmasing $250 \mathrm{gr}, 100 \mathrm{gr}$ gula pasir, 1/4 sendok teh garam, $250 \mathrm{ml}$ air, dan $30 \mathrm{gr}$ tepung maizena.

2. Tahap Pelaksanaan dan Metode

Pelaksanaan kegiatan pelatihan diawali dengan pemaparan materi dengan menggunakan metode ceramah tentang kolang-kaling sebagai pedoman dan pengetahuan awal untuk melakukan praktik. Selesai pemaparan materi dan tanya jawab, dilanjutkan dengan kegitan pelatihan pembuatan selai kolavsa.

\section{Hasil dan Pembahasan}

Kegiatan pengabdian kepada masyarakat dengan mengangkat tema pelatihan entrepreneurship melalui pembuatan selai kolavsa (kolang-kaling varian rasa) dilaksanakan oleh tim pengabdian dari Program Studi Pendidikan Biologi Universitas Majalengka di Blok Galasri RT. 014 RW. 006 Desa Sagara Kecamatan Argapura Kabupaten Majalengka tepatnya di rumah pengusaha kolang-kaling bapak Nanang Mustopa dan istri. Kegiatan pelatihan ini diikuti oleh 15 orang peserta yang terdiri dari karyawan dan masyarakat sekitar. Peserta yang mengikuti kegiatan ini wajib mengisi daftar hadir yang telah disediakan oleh tim pengabdian.

Setelah selesai melakukan pendaftaran peserta, acara dilanjutkan dengan pemamaparan materi dari tim pengabdian sebagai pengetahuan awal tentang kolangkaling dan resep pembuatan selai kolavsa. Pemaparan materi dilakukan dengan menggunakan metode ceramah menggunakan media power point dan proyektor. 

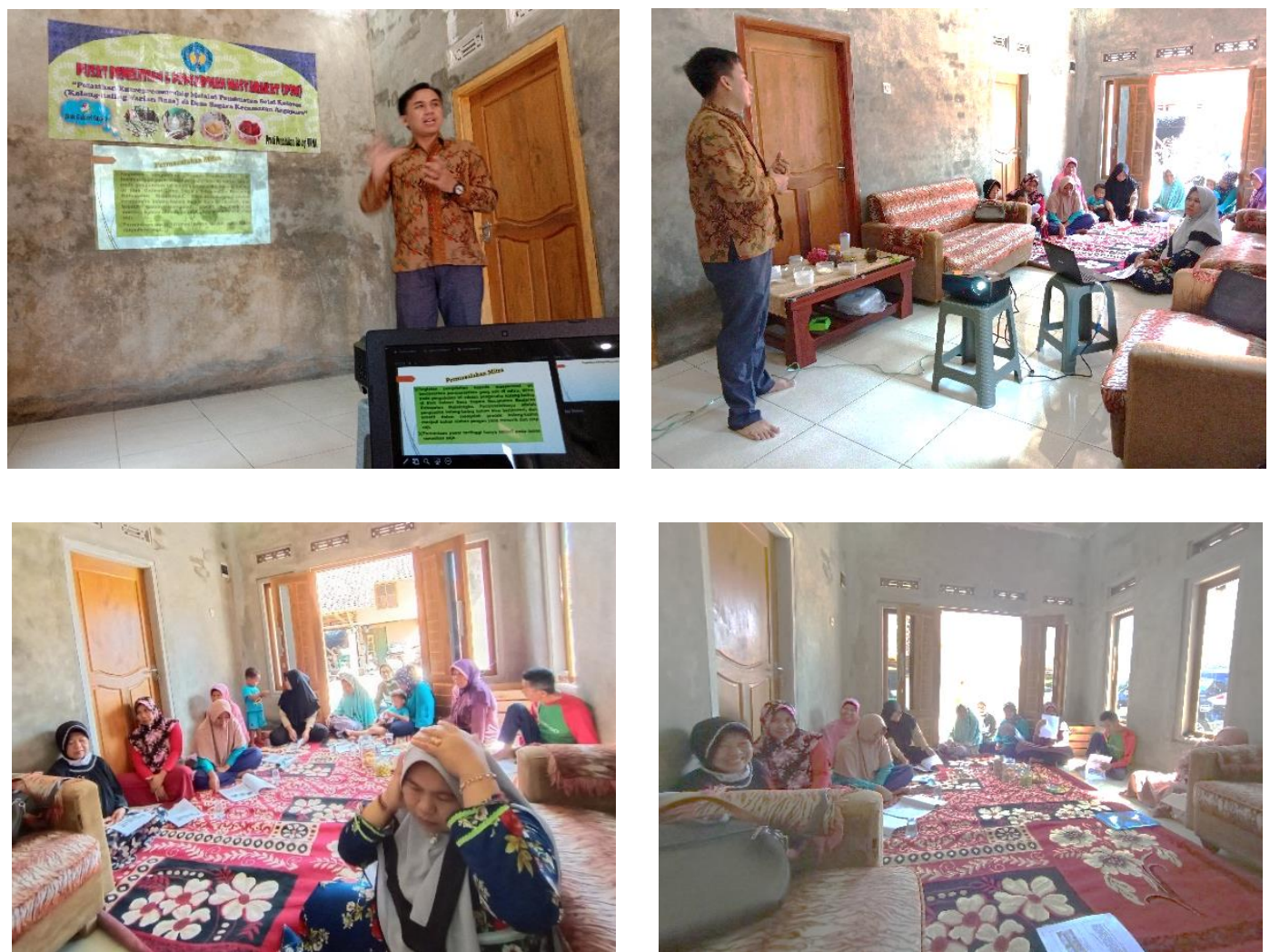

Gambar 3. Pemaparan Materi Pelatihan

Ketika tim sedang memaparkan materi peserta sambil mengkaji terhadap print out materi yang di dalamnya sudah terdapat resep pembuatan selai kolavsa. Setelah selesai pemamparan materi peserta diberi kesempatan untuk melakukan tanya jawab. Banyak peserta yang antusias dalam mengikuti kegiatan pelatihan ini, terlihat dari rasa ingin tahu peserta yang dinilai cukup tinggi terhadap pembuatan selai kolavsa dengan mengajukan pertanyaan diantaranya tentang proses pembuatannya, proses pengemasan, penetuan harga jual, proses pemasaran, dan daya kolang-kaling setelah diolah menjadi selai kolavsa.
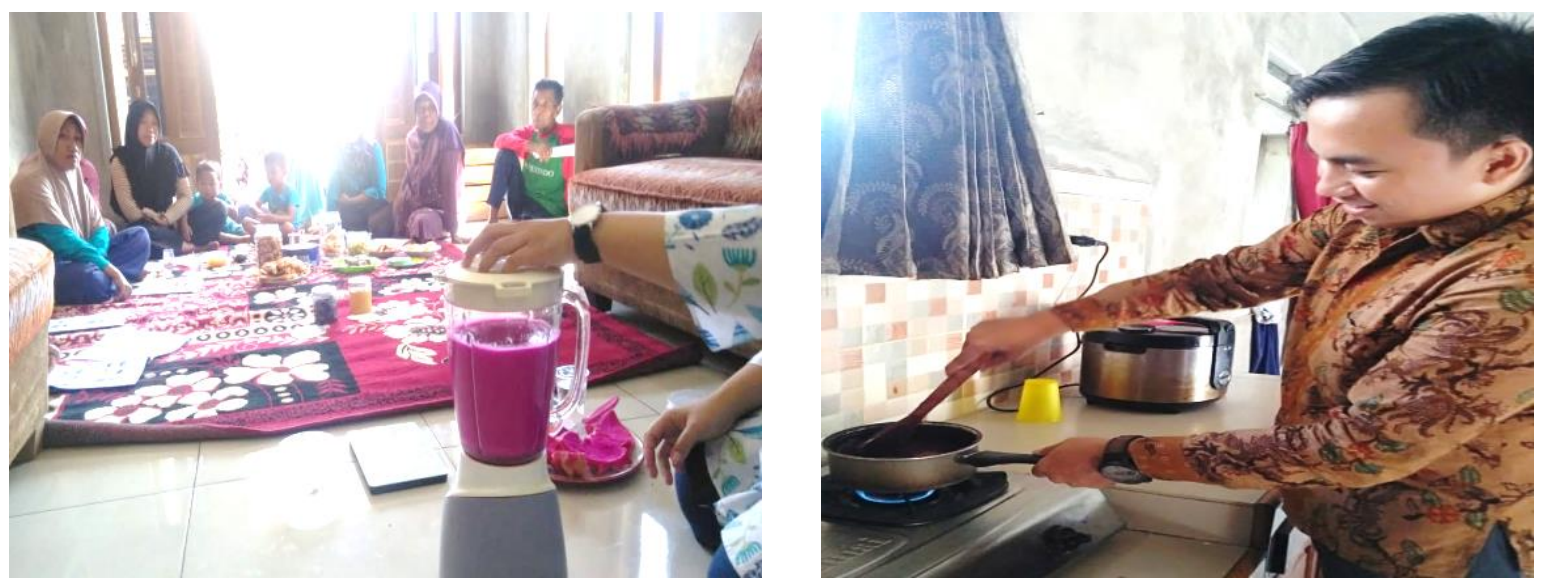

Gambar 4. Proses Pembuatan Selai Kolavsa 
Proses pemaparan materi dan tanya jawab selesai, peserta dihadapkan untuk melaksanakan praktik secara langsung pembuatan selai kolavsa. Pada kesempatan ini peserta melakukan praktik pembuatan selai kolavsa varian rasa buah naga, untuk varian rasa nanas dan cokelat sudah dibuat terlebih dahulu oleh tim pengabdian sebelum melaksanakan kegiatan pelatihan. Berikut dokumentasi proses pembuatan selai kolavsa varian rasa buah naga.

Proses masak selai kolavsa menggunakan api kecil, dan harus diaduk-aduk sampai adonan selai menjadi kalis menyerupai bubur. Apabila tidak diaduk-aduk adonan selai akan menjadi gosong dan membentuk caramel. Bahan-bahan selai harus sesuai dengan takarannnya kalau kelebihan atau kekurangan sedikit, maka selai tidak akan jadi dengan hasil yang bagus. Setelah adonan selai kalis, segera matikan api dan angkat selai tersebut. Tahap selanjutnya selai harus didinginkan terlebih dahulu, tidak perlu diadukaduk untuk proses mendinginkan cukup dengan didiamkan saja 10 menit. Selai yang sudah mengalami tahap pendinginan, segera masukkan kedalam wadah atau kemasan usahakan harus tertutup rapat agar tidak ada udara yang masuk.
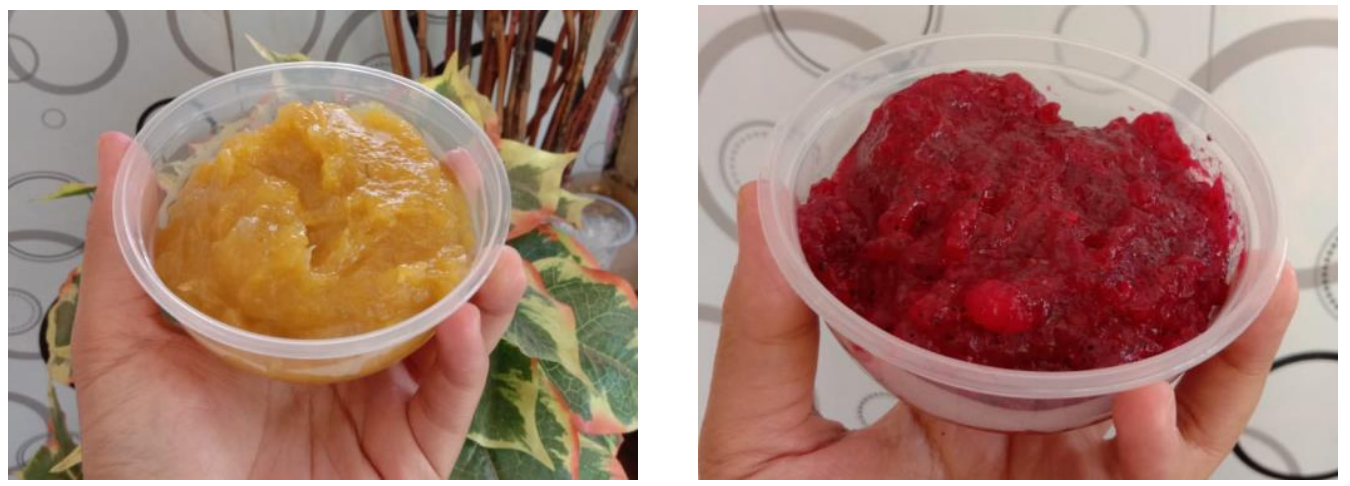

Gambar 5. Tekstur Selai Kolavsa

Selai yang dipraktikkan pada pelatihan ini tanpa tambahan pengawet, jadi harus segera dimasukkan ke dalam lemari es. Selai yang disimpan dalam lemari es akan bertahan $5-7$ hari. Apabila ingin membuat selai yang bisa bertahan lebih lama, yaitu dengan cara menambahkan asam benzoat / natrium benzoat. Natrium benzoate berperan dlam penghambatan pertumbuhan mikroorganisme yang berbahaya, sehingga dapat mencegah proses pembusukan. Natrium benzoat sangat mudah untuk didapatkan karena dijual di toko bahan-bahan kue.
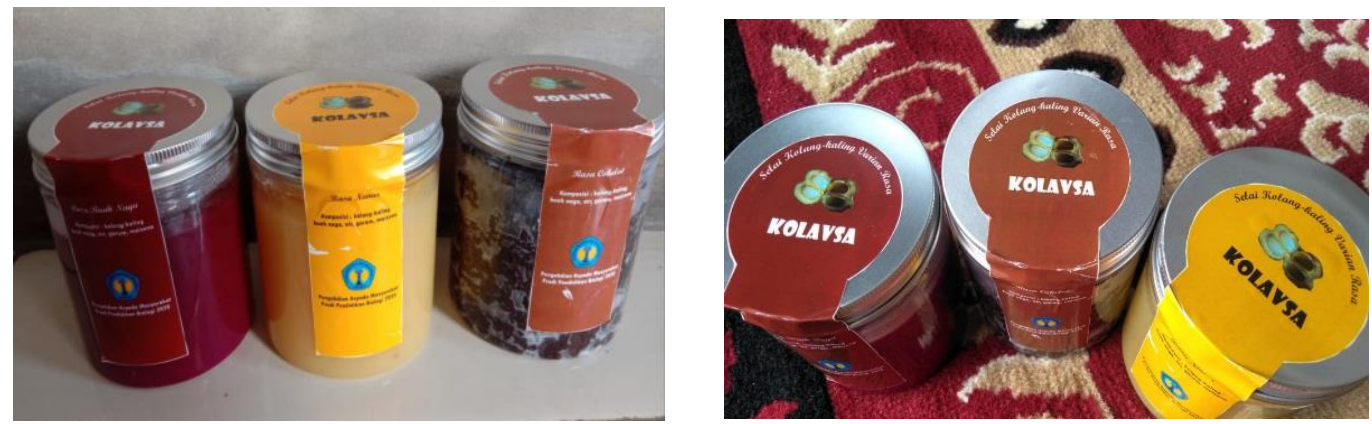

Gambar 6. Kemasan Selai Kolavsa 

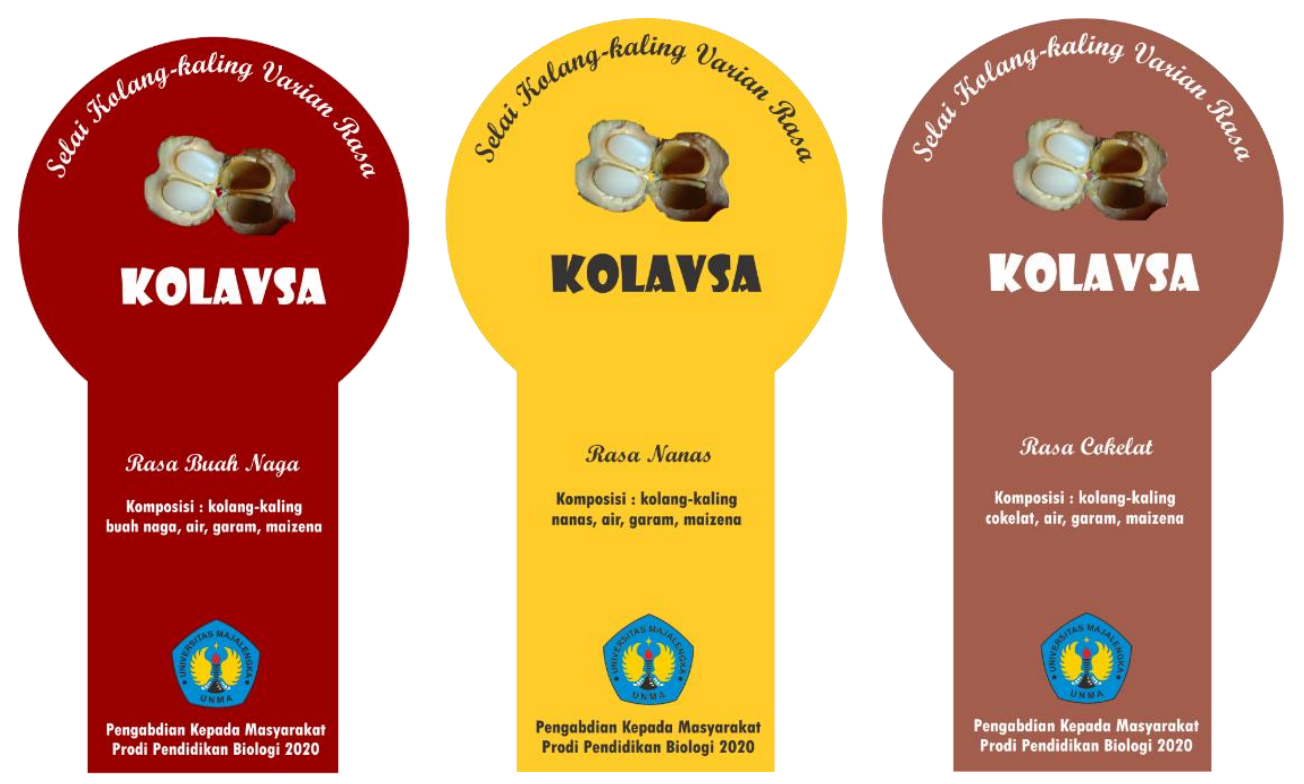

Gambar 7. Label Selai Kolavsa

\section{Respon Peseta Terhadap Materi Pelatihan}

Persentase respon peserta terhadap materi pelatihan menunjukkan sebagian besar setuju dengan persentase sebesar $64 \%$, bahkan ada responden yang memilih sangat setuju sebesar $28 \%$, sisanya responden menjawab kurang setuju $6 \%$, dan tidak setuju $2 \%$. Persentase respon peserta terhadap materi dapat digambarkan pada grafik berikut.

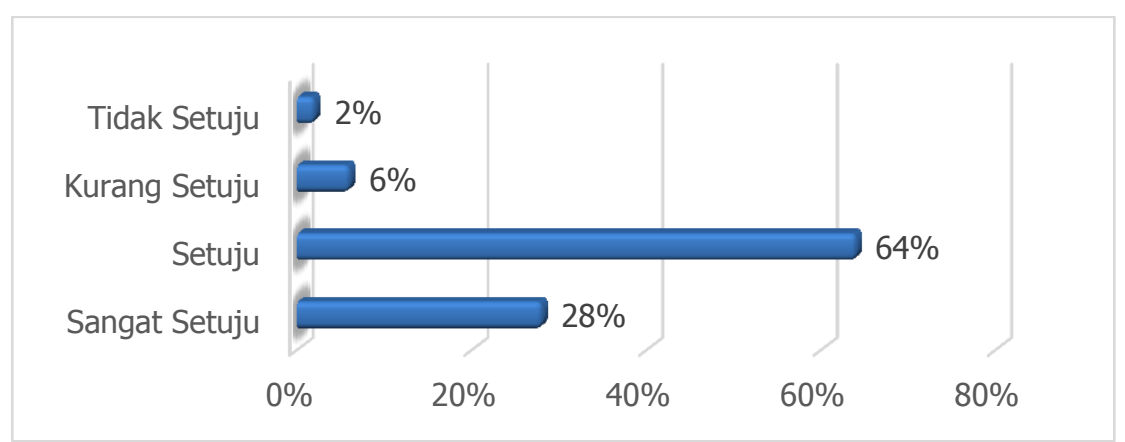

Gambar 8. Respon Peserta Terhadap Materi Pelatihan

Grafik pada gambar 8 menunjukkan bahwa respon peserta terhadap materi pelatihan mempunyai respon positif yang karena banyak memilih jawaban setuju dan sangat setuju. Berdasarkan persentasi responden yang tinggi pada alternatif jawaban setuju dan sangat setuju maka dapat disimpulkan bahwa materi yang dipaparkan saat pelatihan berkategori sudah sangat baik.

2. Respon Peserta Terhadap Metode Pelatihan

Metode pelatihan yang digunakan pada pelatihan ini adalah ceramah dan praktik. Respon peserta terhadap metode pelatihan yang digunakan sebagian besar menjawab sangat setuju sebesar 55\%, responden yang memilih alternatif jawaban setuju sebesar40\%, sedangkan sisanya memilih alternatif jawaban kurang setuju 4\% dan tidak setuju $2 \%$. Persentase respon peserta terhadap metode pelatihan dapat digambarkan pada grafik berikut. 


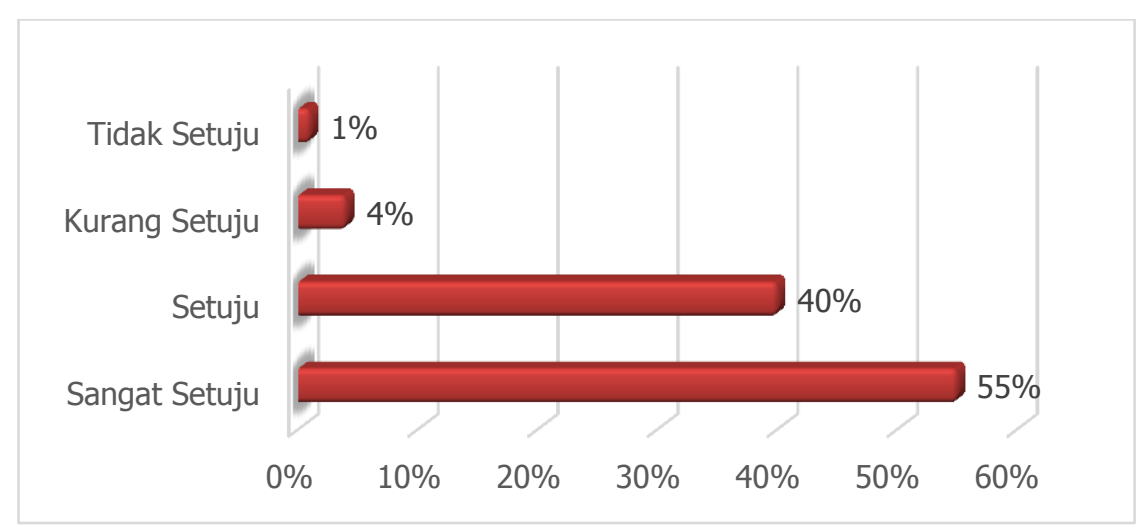

Gambar 9. Respon Peserta Terhadap Metode Pelatihan

Grafik pada gambar 9 menunjukkan bahwa respon peserta terhadap metode pelatihan mempunyai respon positif karena banyak yang memilih jawaban setuju dan sangat setuju. Berdasarkan persentasi responden yang tinggi pada alternatif jawaban sangat setuju dan setuju, maka dapat disimpulkan bahwa metode pelatihan yang digunakan saat pelatihan berkategori sudah sangat baik.

\section{Kesimpulan}

Kegiatan pelatihan entrepreneurship melalui pembuatan selai kolavsa ini, dapat berjalan dengan baik dan lancar. Peserta pelatihan mendapatkan ilmu tentang inovasi pengolahan kolang-kaling menjadi makanan yang menarik dan siap saji. Selain itu, peserta juga dapat mengetahui teknik pemasaran selai kolavsa secara online dan ofline dengan cara menitipkan produknya di pusat oleh-oleh Majalengka. Selai kolavsa diharapkan dapat menambah penghasilan dan meningkatkan penjualan kolang-kaling diluar bulan Syaban dan Ramadhan. Kegiatan lanjutannya yaitu dengan cara kunjungan kembali untuk melakukan evalusi hasil uji coba pembuatan selai kolavsa yang telah ditugaskan kepada masing-masing peserta, agar peserta lebih termotivasi untuk melakukan usaha secara kreatif dan inovatif sehingga dapat menciptakan produk oleholeh khas Majalengka.

\section{Daftar Pustaka}

Asben, A., Taib, G., \& Rahmawati, Y. (2019). Studi Karakteristik Selai Kolang Kaling Markisa dengan Penambahan Pewarna Angkak. Journal of Applied Agricultural Science and Technology, 3(1), 1-14.

Berta, S., Koapaha, T., \& Mandey, L. (2017). Pemanfaatan kolang-kaling buah aren dan nanas (Ananas comosus I. merr.) dalam pembuatan sliced jam. Jurnal COCOS, (1) 8, hlm 52-62.

Fitri, A., Rismayadi, B., \& Maemunah, M. (2020). Pelatihan Kewirausahaan Tentang Bisnis Rumahan Bagi Ibu Rumah Tangga Di Desa Rengasdengklok Selatan Kecamatan Rengasdengklok Kab Karawang. BERNAS: Jurnal Pengabdian Kepada Masyarakat, 1(1), 22-31. 
Hadiyati, E. (2012). Kreativitas dan inovasi pengaruhnya terhadap pemasaran kewirausahaan pada usaha kecil. Asian Journal of Innovation and Entrepreneurship, 1(03), 135-151.

Harini, S. (2014). Pengaruh Pelatihan Entrepreneurship dan manajemen usaha terhadap pendapatan Usaha Mikro makanan dan minuman. Jurnal Entrepreneur dan Entrepreneurship, 3(1, 2), 73-80.

Lempang, Mody. (2012). Pohon Aren dan Manfaat Produksinya. Jurnal Buletin Eboni, (9) $1, \mathrm{hlm}$ 37-54.

Lumpkin, G.T. \& Dess, G.G. (1996). Clarifying the Entrepreneurial Orientation Construct and Linking It to Performance. Academy of Management Review, 21: 135-172.

Novayanti, S. R. (2016). Pengaruh Penambahan Konsentrasi Gula terhadap Sifat Organoleptik pada Manisan Kolang Kaling. Digital Repository Unila, Tersedia : [online] http://digilib.unila.ac.id/25227/

Riza, E. (2016). Karakteristik Selai Kolang-Kaling Dengan Campuran Buah Nangka (Artocarpus Heterophyllus). Doctoral dissertation, Universitas Andalas. 